Perrin, J. (1952). J. gen. Microbiol. 6, 143-148

\title{
Observations on the Relationship between Viruses of the Psittacosis-Lymphogranuloma Group and the Rickettsiae
}

\author{
By J. PERRIN \\ The Bacteriological Department, The London Hospital Medical College, \\ Whitechapel, London, E. 1
}

\begin{abstract}
SUMMARY: Changes in the metabolism of the chick embryo host cell produced by $p$-aminobenzoic acid or sodium cyanide did not influence the multiplication of psittacosis or Newcastle virus. A suspension of psittacosis virus was unable to catalyse oxygen uptake in presence of glutamic acid, casein hydrolysate, succinic or pyruvic acids. The results suggest that, in its relation to certain metabolic activities of the host cell, psittacosis virus more nearly resembles the true viruses than the Rickettsiae.
\end{abstract}

The systematic position of the psittacosis-lymphogranuloma group of infective agents is still a matter of dispute. Some authorities, impressed by the resemblances of these agents to the Rickettsiae, have suggested that they should be grouped with them. Lillie (1930), who was one of the first to make a morphological study of psittacosis virus, stated that he considered it to be a rickettsia, naming it Rickettsia psittaci; others retain these agents with the viruses. A third view is that they form a group by themselves, occupying a position intermediate between the rickettsiae and what are termed the 'true viruses'. Admittedly the agents of the psittacosis-lymphogranuloma group resemble the rickettsiae in some respects. They have a similar affinity for basic dyes which appears to be related to their high content of deoxyribonucleic acid (Lépine \& Sautter, 1946). Although, in general, they are smaller than the rickettsiae they are not dissimilar in this respect from $R$. burneti. They produce intracellular colonies which resemble those of the rickettsiae rather than the inclusions of the true viruses, and their susceptibility to sulphonamides and some natural antibiotics, though differing in some respects from that of the rickettsiae, suggests a closer resemblance to the latter than to the viruses. There are, however, points of difference. The agents of the psittacosis-lymphogranuloma group do not appear in bacillary form as do the rickettsiae, and when multiplying they pass through a cycle of development not seen in the rickettsiae. A more important dissimilarity is the difference in host range: the rickettsiae are essentially parasites of arthropods, though some species have also acquired mammalian hosts, whereas none of the viruses of the psittacosis-lymphogranuloma group has an insect host. The recent work of Greiff \& Pinkerton (1948) may well have a bearing on the question of the relationship of the psittacosis-lymphogranuloma group to the viruses on the one hand, and the rickettsiae on the other. These workers found that injection of $p$-aminobenzoic acid (PAB) into the developing hen's egg increased the metabolism of the cells of the embryo as measured by respiratory exchange, making them in consequence unsuited to the multiplication of typhus 
rickettsiae; potassium cyanide had the reverse effect. Zinsser \& Schoenbach (1937) claimed that an essential difference between rickettsiae and viruses is that the former begin to multiply in cells when cell metabolism has diminished, whereas viruses require for multiplication cells at the height of their metabolic activity. In the light of these observations it seemed of importance to repeat the work of Greiff \& Pinkerton with a virus of the psittacosis-lymphogranuloma group. Similarly, the investigations of Bovarnick \& Snyder (1949) showing the ability of typhus rickettsiae preparations to catalyse the uptake of oxygen in the presence of certain substrates, in particular glutamic acid, have a bearing on this problem and it was thought of interest to see whether a virus of the psittacosis-lymphogranuloma group behaved in a similar manner. Psittacosis virus was chosen for this purpose, with Newcastle disease virus, representing the true viruses, as a control.

\section{Effect of p-aminobenzoic acid and of sodium cyanide on the growth of psittacosis virus in the yolk sac of the developing chick embryo}

Psittacosis virus. Strain MOH 154 (isolated from a parrot in 1940; maintained in the mouse until 1945; established in eggs after that date); material from the 146th to the 158th egg passage was used.

Chick embryos. Fertile eggs were incubated at $39^{\circ}$ before inoculation. After inoculation they were incubated at $35^{\circ}$ until harvested.

p-Aminobenzoic acid. Aqueous solution, $16 \mathrm{mg} . / \mathrm{ml}$.; dose used $0.2 \mathrm{ml}$.

Sodium cyanide. Aqueous solution, $0.5 \mathrm{mg} . / \mathrm{ml}$.; dose used 0.2 or $0.4 \mathrm{ml}$. Both these solutions were sterilized by means of sintered glass filters (porosity L 5).

Technique. The PAB or sodium cyanide solution was injected into the air sac of the embryo (in some experiments into the yolk sac). Preliminary experiments, using methylene blue or estimations of PAB in various parts of the embryo, established that rapid diffusion of electrolytes across the shell membrane into all parts of the embryo occurred. Where double inoculation of eggs was necessary, injection into the air sac diminished trauma to a negligible degree. PAB was always introduced $48 \mathrm{hr}$. before virus since, as Greiff \& Pinkerton showed, the maximum effect on metabolism of the embryo occurs on the fourth day following inoculation. Furthermore, even dilute suspensions of psittacosis virus killed embryos in approximately 4 days, so that if virus and PAB had been injected simultaneously there would have been insufficient time for the maximum effect. In contrast, sodium cyanide has an almost immediate effect on metabolism and so could be inoculated at the same time as the virus. Virus was inoculated direct into the yolk sac. In certain experiments both virus and $\mathrm{PAB}$ or sodium cyanide were injected directly into the yolk sac.

In each experiment two series of embryos were used: a control series received saline injected into the air sac, and the test series received a dose of PAB or sodium cyanide. Both series were then injected with an equal dose of psittacosis virus. On the fourth day following infection the majority of embryos in both series were dead or moribund. All yolk sacs were harvested 
into normal saline, one yolk sac/2 $\mathrm{ml}$. saline. Embryos dying on the first or second day following infection with virus were discarded as non-specific deaths.

Estimation of virus growth. Individual yolk sac impression preparations were made and stained by Castaneda's method. All the yolk sacs in each group were then pooled, ground in a Tenbroeck tube, and after sedimentation overnight in the refrigerator, smears were made from the supernatant fluids and compared. A crude system of marking from \pm to ++++ was then accorded to the virus content of these preparations.

\section{Results with psittacosis virus}

Neither PAB nor cyanide in the concentrations used influenced the rate of multiplication of psittacosis virus in the yolk sac of the developing chick embryo. Since impression preparations of individual yolk sacs showed considerable variation, a variation which might well be due to chance, only the findings in the smears made from pooled suspensions are recorded. Thus when PAB (3.3 mg./sac) was injected into the yolk sac of ten embryos the smear of the pool scored ++ amounts of virus, the same as the score of the pool of nine control embryos. Similarly, the scores were equal in the pool of eight embryos injected with $\mathrm{PAB}$ in the air sac and the eight-embryo control pool. Sodium cyanide $(0 \cdot 2 \mathrm{mg}$./air sac) gave a score of ++ in an eight-embryo pool and the same for a nine-embryo control pool; $0.1 \mathrm{mg}$. NaCN/yolk sac gave + in test pool (9) and also + in control pool (7). There is nothing in these results to suggest that either PAB or cyanide influenced the growth of psittacosis virus, a finding supported by the fact that approximately equal numbers of embryos in the control and experimental series were dead or moribund on the fourth day.

\section{Effect of p-aminobenzoic acid and sodium cyanide on the growth of Nerwcastle} virus in the chorio-allantoic membrane of the developing chick embryo

Newcastle virus. An egg-adapted strain received from Mr T. M. Doyle, F.R.C.V.S. was used. Saline suspensions of freshly harvested infected allantoic fluid (10 to 12-day embryos) or of reconstituted freeze-dried material were used in dilutions of $10^{-5}$ in an inoculum of $0.1 \mathrm{ml}$. As far as possible the minimum infecting dose was established for each preparation by titration in embryos of the same age as those used in the actual experiments.

Chick embryos. Ten to twelve-day embryos were used, the temperatures of incubation being the same as those used for the psittacosis experiments.

Technique of procedure. This was like that used with psittacosis virus except that Newcastle virus was injected by the allantoic route. Allantoic fluids were harvested from both series at the end of $48 \mathrm{hr}$. and their virus content estimated by haemagglutination.

Haemagglutination. The Salk (1944) method was followed, using either fowl or human red cells. Results were read after allowing sedimentation of cells at $+4^{\circ}$ for $6 \mathrm{hr}$. The end-point titre was taken as the reciprocal of highest dilution 
in which red cells were completely dispersed on the bottom of the tube without ring formation. A pro-zone, probably due to interference by yolk, was met in some titrations; where this occurred in association with a low haemagglutinin titre a clear end-point was not always obvious. Since this phenomenon occurred in both groups with approximately equal frequency it did not invalidate comparison between the two.

\section{Results with Nerwcastle virus}

As with psittacosis virus, neither cyanide nor PAB could be shown to influence the rate of multiplication of Newcastle virus in allantoic fluid as estimated by haemagglutination (Tables 1 and 2). In Exp. 3 (Table 2) some embryos in both groups were alive at the time of harvesting and no virus was detected. This was presumed to be due to the infecting dose of virus having been a minimum infecting dose. It was the deliberate aim in these experiments to keep the infecting dose at this level in order to reveal any small influence which cyanide or PAB might have on the growth of the viruses.

Table 1. The effect of $P A B$ on the groroth of Nervcastle virus in the chick embryo

PAB injected by air sac route. Virus estimated by agglutination of fowl red cells.

\begin{tabular}{|c|c|c|c|c|c|}
\hline \multirow{2}{*}{$\begin{array}{c}\text { Dose } \\
\text { of } \\
\text { PAB } \\
\text { (mg.) }\end{array}$} & \multirow[b]{2}{*}{$\begin{array}{c}\text { Virus } \\
\text { inoculum }\end{array}$} & \multicolumn{2}{|c|}{ PAB series } & \multicolumn{2}{|c|}{ Control series } \\
\hline & & $\begin{array}{l}\text { No. of } \\
\text { embryo }\end{array}$ & Titre & $\begin{array}{l}\text { No. of } \\
\text { embryo }\end{array}$ & Titre \\
\hline \multicolumn{6}{|c|}{ Exp. 1} \\
\hline \multirow[t]{7}{*}{$6 \cdot 6$} & Freeze dried & 1 & 5,120 & 1 & 10,240 \\
\hline & material; $0.1 \mathrm{ml}$ & 2 & 40,960 & 2 & 10,240 \\
\hline & of $10^{-5}$ dilution & 3 & 10,240 & $\overline{3}$ & 20,480 \\
\hline & & 4 & 10,240 & 4 & 10,240 \\
\hline & & $\mathbf{5}$ & 10,240 & 5 & - \\
\hline & & 6 & 5,120 & 6 & 10,240 \\
\hline & & 7 & 5,120 & 7 & 20,480 \\
\hline \multicolumn{6}{|c|}{ Exp. 2} \\
\hline \multirow[t]{10}{*}{$\mathbf{3 \cdot 3}$} & Freeze dried & 1 & 5,120 & 1 & 2,560 \\
\hline & material; $0.1 \mathrm{ml}$ & 2 & 160 & 2 & - \\
\hline & of $10^{-5}$ dilution & $\mathbf{3}$ & 10,240 & $\mathbf{3}$ & 10,240 \\
\hline & & 4 & $\mathbf{3 2 0}$ & 4 & 10,240 \\
\hline & & $\mathbf{5}$ & - & 5 & 10,240 \\
\hline & & 6 & 2,560 & 6 & 10,240 \\
\hline & & $y$ & $40(i)$ & 7 & 10,240 \\
\hline & & 8 & 10,240 & 8 & 5,120 \\
\hline & & 9 & 20,480 & 9 & 10,240 \\
\hline & & 10 & $d$ & 10 & 5,120 \\
\hline
\end{tabular}

$d=$ eggs dead after $24 \mathrm{hr}$. and discarded; $-=$ no virus detected; $(i)=$ incomplete dispersion of red cells at end point.

Inability of psittacosis virus to catalyse oxidation of certain substrates

The technique used was that described by Bovarnick \& Snyder (1949), and respiratory exchange was measured in the conventional Warburg apparatus. Psittacosis virus was harvested in the same buffer as that used by these authors, but the method of preparing the virus suspension differed from their technique 
Table 2. The effect of sodium cyanide on the growth of Nerocastle virus in chick embryo

Sodium cyanide injected by air sac route. Virus estimated by agglutination of human red cells.

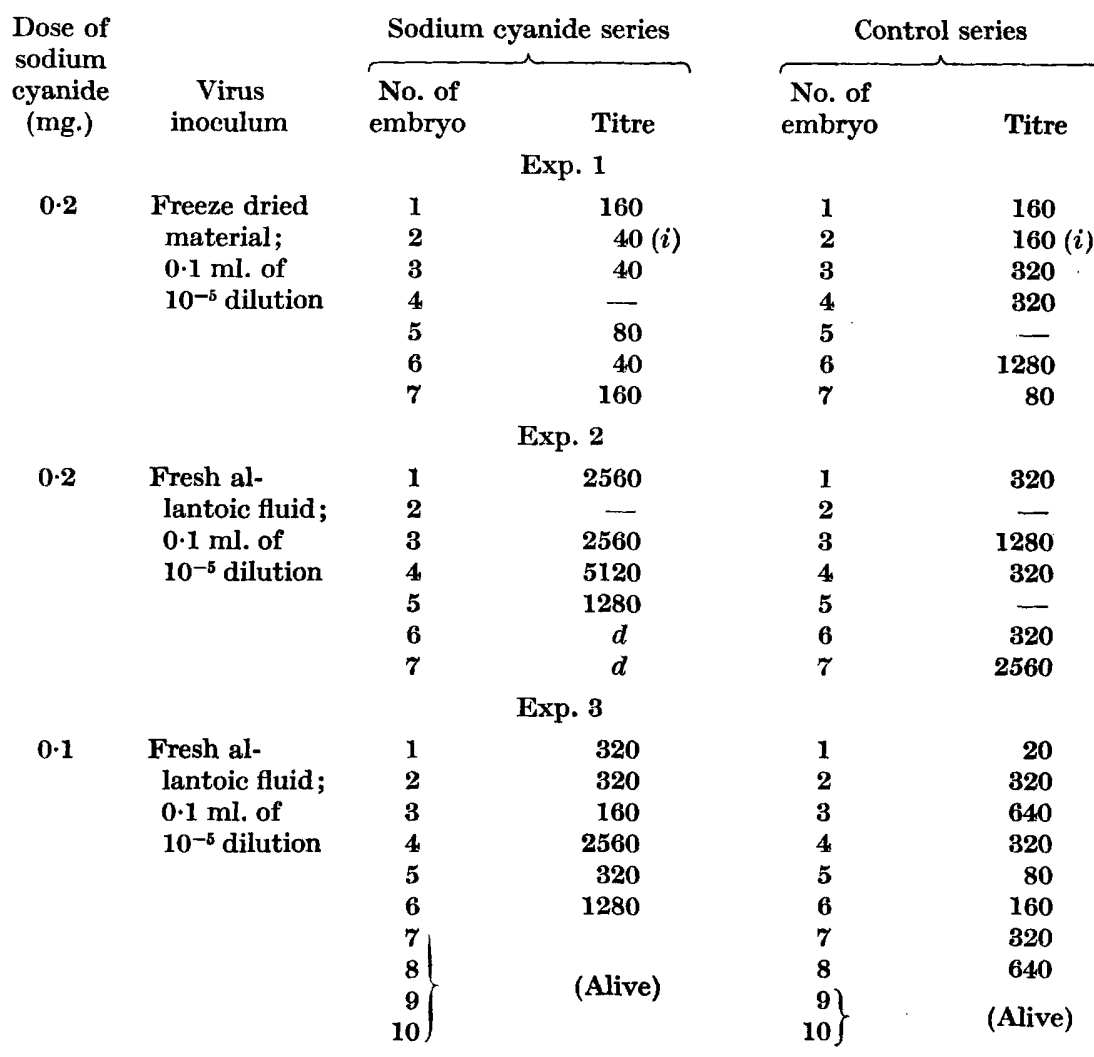

Symbols as in Table 1.

with rickettsiae. Infected yolk sacs from 8- to 9-day chick embryos were harvested in the proportion of one yolk sac/2.5 ml. buffer ( $\mathrm{pH} \mathrm{7.5)}$. The intact yolk sacs were gently shaken and the suspensions centrifuged at 2500 r.p.m. for $15 \mathrm{~min}$. The supernatant was pipetted off, care being taken not to disturb the surface disk of yolk and fat. By this method a rich yield of virus containing few, if any, cells was obtained. More violent methods of triturating yolk sacs released cellular material without greatly increasing the virus content.

Examination for oxygen uptake in Warburg apparatus. All experiments were performed at a water-bath temperature of $36^{\circ}$. The mixture in each Warburg flask consisted of: $1.5 \mathrm{ml}$. psittacosis virus suspension; $0.2 \mathrm{ml}$. of solution containing $\mathrm{MgCl}_{2}(0.012 \mathrm{M})$ and $\mathrm{MnCl}_{2}(0.004 \mathrm{M}) ; 0.5 \mathrm{ml}$. substrate neutralized with $\mathrm{KOH}$ at the indicated concentration; $0.2 \mathrm{ml}$. of a salt solution ( $\mathrm{pH} 7 \cdot 5$ ) consisting of $0.126 \mathrm{M}-\mathrm{KCl}, 0.0012 \mathrm{M}-\mathrm{KH}_{2} \mathrm{PO}_{4}, 0.0106 \mathrm{M}-\mathrm{Na}_{2} \mathrm{HPO}_{4}$. The substrates used were: casein hydrolysate, $0.3 \%$; glutamic acid, $0.0125 \mathrm{M}$; 
succinic acid $0.0125 \mathrm{M}$; pyruvic acid 0.004 M. A control was included in each experiment consisting of $1.5 \mathrm{ml}$. normal yolk sac suspension in place of psittacosis virus suspension. Manometer readings were taken over a period of $4 \mathrm{hr}$. No respiratory activity of psittacosis virus could be demonstrated in the presence of any of the four substrates tested.

I am extremely grateful to Prof. S. P. Bedson, who suggested and supervised this work. My thanks are also due to Mr L. W. J. Bishop for much technical assistance.

\section{REFERENCES}

Bovarnick, M. R. \& SNyder, J. C. (1949). Respiration of typhus rickettsiae. J. exp. Med. 89, 561.

GreifF, D. \& Pinkerton, H. (1948). Effect of enzyme inhibitors and activators on the multiplication of typhus rickettsiae. III. Correlation of effects of PABA and KCN with oxygen consumption in embryonate eggs. J. exp. Med. 87, 175.

Lápine, P. \& Sautter, V. (1946). Étude histochemique des lésions dues aux ultravirus les acides nucléiques. Ann. Inst. Pasteur, 72, 174.

Lrute, R. D. (1930). Psittacosis: rickettsia-like inclusions in man and in experimental animals. Publ. Hlth Rep., Wash. 45, 773.

SALK, J. E. (1944). A simplified procedure for titrating haemagglutinating capacity of influenza virus and the corresponding antibody. J. Immunol. 49, 87.

Zinsser, H. \& Schoendach, E. B. (1937). Studies on the physiological conditions prevailing in tissue cultures. J. exp. Med. 66, 207.

(Received 27 July 1951) 